\title{
Acyl-CoA-binding protein (ACBP): the elusive 'hunger factor' linking autophagy to food intake
}

\author{
José Manuel Bravo-San Pedro ${ }^{1-3}$, Valentina Sica ${ }^{1-3}$, Frank Madeo ${ }^{4,5}$ and Guido Kroemer ${ }^{1-3,6-8, *}$ \\ ${ }^{1}$ INSERM U1138, Centre de Recherche des Cordeliers, Sorbonne Université, Université de Paris, 15 rue de l'école de médecine \\ 75006, Paris, France. \\ 2 Team “Metabolism, Cancer \& Immunity” labellisée par la Ligue contre le Cancer, Paris, France. \\ ${ }^{3}$ Cell Biology and Metabolomics platforms, Gustave Roussy Cancer Campus, Villejuif, France. \\ ${ }^{4}$ Institute of Molecular Biosciences, NAWI Graz, University of Graz, Graz, 8010, Austria. \\ ${ }^{5}$ BioTechMed Graz, Graz, 8010, Austria. \\ ${ }^{6}$ Pôle de Biologie, Hôpital Européen Georges Pompidou, AP-HP, Paris, France. \\ 7 Suzhou Institute for Systems Medicine, Chinese Academy of Sciences, Suzhou, China. \\ 8 Karolinska Institute, Department of Women's and Children's Health, Karolinska University Hospital, Stockholm, Sweden. \\ * Corresponding Author: \\ Guido Kroemer, E-mail: kroemer@orange.fr
}

ABSTRACT The best-known appetite-regulating factors identified in rodents are leptin, an appetite inhibitor, and ghrelin, an appetite stimulator. Rare cases of loss-of-functions mutations affecting leptin and its receptor, as well as polymorphisms concerning ghrelin and its receptor, have been documented in human obesity, apparently validating the relevance of leptin and ghrelin for human physiology. Paradoxically, however, the overwhelming majority of obese individuals manifest high leptin and low ghrelin plasma levels, suggesting that both factors are not directly disease-relevant. We recently discovered that acyl-CoA-binding protein (ACBP), also known as diazepam-binding inhibitor (DBI), acts as an efficient lipogenic and appetite stimulator in mice. Indeed, in response to starvation, ACBP/DBI is released from tissues in an autophagy-dependent fashion and increases in the plasma. Intravenous injection of $A C B P / D B I$ stimulates feeding behavior through a reduction of circulating glucose levels, and consequent activation of orexigenic neurons in the hypothalamus. In contrast, neutralization of ACBP/DBI abolishes the hyperphagia observed after starvation of mice. Of note, $A C B P / D B I$ is increased in the plasma of obese persons and mice, pointing to a convergence (rather than divergence) between its role in appetite stimulation and human obesity. Based on our results, we postulate a novel 'hunger reflex' in which starvation induces a surge in extracellular $A C B P / D B I$, which in turn stimulates feeding behavior. Thus, ACBP/DBI might be the elusive 'hunger factor' that explains increased food uptake in obesity. doi: $10.15698 /$ cst2019.10.200

Received originally: 22.08 .2019

in revised form: 19.09.2019,

Accepted 20.09.2019,

Published 24.09.2019.

Keywords: appetite control, diazepam binding protein, metabolism, obesity, unconventional protein secretion.

\section{Abbreviatons:}

ACBP - Acyl-CoA-binding protein AcCoA - acetyl coenzyme A, $C R M$ - caloric restriction mimetic, $D B I$ - diazepam-binding protein.
Overweight has beaten undernutrition as the most frequent pathological state throughout the world, affecting close to $25 \%$ of the adult population. This has severe implications for global health, given that obesity is the major risk factor for most if not all non-communicable diseases, including the entire spectrum of cardiovascular, neoplastic, metabolic and neurodegenerative diseases. Among the G20 countries, the US is the uncontested leader (adult obesity rate $36 \%$ ) followed by countries with a rate of 30 $35 \%$ (Saudi Arabia, Turkey), a large group of countries with a rate of $20-30 \%$ (Argentina, Australia, Brazil, Canada, France, Germany, Mexico, Russia, South Africa, United Kingdom), one European Country that is just undercutting $20 \%$ (Italy) and a group of Asian Countries with obesity rates well under $10 \%$ (China, India, Indonesia, Japan, South Korea). These numbers (http://worldpopulationrev iew.com) eloquently underscore the cause of the obesity pandemic, which is the Western lifestyle characterized by excessive consumption of calories (and in particular carbo- 
hydrates and ultra-processed food) coupled to sedentarism, as well as the failure of public health education [1-4].

In spite of the extremely high prevalence of obesity, multiple studies have been designed to define genetically determined 'risk factors' that would explain why only one third of the population reaches a body mass index (BMI) $>30$ [5-7]. Such studies were spurred by the discovery of leptin, the satiety hormone. Loss-of-function mutation of leptin in mice causes hyperphagy and obesity (in $\mathrm{Ob} / \mathrm{Ob}$ mice), as does that of its receptor (in $D b / D b$ mice) $[8,9]$. Later exceptionally rare cases of human obesity with mutations in the genes coding for leptin or its receptor were described $[10,11]$. However, the vast majority of obese patients exhibit an increase in circulating leptin levels (perhaps as a failing homeostatic mechanism in which leptin levels are upregulated yet fail to tame appetite), meaning that leptin deficiency is not a major pathogenic factor in obesity [12-14]. Other studies have led to the discovery of a major appetite-stimulatory factor, ghrelin, in rodents [15] However, obese patients exhibit a decrease in circulating ghrelin levels (again, likely as a failing homeostatic mechanism), indicating that excessive ghrelin cannot be the cause of human obesity $[16,17]$. Moreover, in patients with anorexia nervosa, ghrelin levels are paradoxically high $[18,19]$, while leptin levels are paradoxically low $[20,21]$. These results indicate that major appetite control circuitries discovered in mice cannot be pharmacologically manipulated to prevent or treat human eating disorders.

In eukaryotes, autophagy is the phylogenetically most ancient response to dwindling nutrient resources, allowing cells and organisms to sequester and to digest nonessential macromolecules contained in the cytoplasm [22, 23]. Continuous or periodic stimulation of autophagy by caloric restriction or intermittent fasting, respectively, improves the fitness of model organisms ranging from yeast to primates [24-28]. Indeed, autophagy is the mechanisms through which constant or periodic limitations in food access increases the healthspan and lifespan of model organ- isms [29-31]. Caloric excess suppresses autophagy, thereby abolishing an important cytoplasmic recycling mechanism, favoring the storage of excessive lipid in a variety of cell types, reducing cellular and organismal fitness, and likely precipitating the manifestation of age-related diseases, which are the 'co-morbidities' of obesity [32, 33]. Indeed, obesity is linked to a state of autophagic suppression [34] and autophagy induction by pharmacologic manipulations has anti-obesity effects [35], suggesting that autophagy inhibition is causally involved in the pathogenic cascade that leads to supraphysiological adiposity $[33,36]$.

Intrigued by these insights, we have been attempting to develop 'caloric restriction mimetics' (CRMs), i.e. pharmacological agents that mimic the biochemical effects of caloric restriction [37-39]. Nutrient deprivation causes autophagy induction through the depletion of the cytosolic pool of acetyl coenzyme $A$ (AcCoA), resulting in deacetylation of cytoplasmic proteins (including a number of proteins involved in the regulation and execution of autophagy), thereby stimulating autophagic flux $[40,41]$. CRMs mimic the effect of caloric restriction because they inhibit enzymes that generate AcCoA (such as ATP citrate lyase) or that use AcCoA for protein acetylation (such as the EP300 acetyltransferase) or, alternatively, stimulate deacetylases (such as sirtuin 1), resulting in autophagy induction [38, 39]. The collection of CRMs includes several compounds reputed for their capacity to extend healthspan and/or lifespan such as aspirin [42], chalcones [43], resveratrol [44] and spermidine $[30,45]$. This latter agent is a natural polyamine present in food items. Epidemiological studies suggest that ingestion of high levels of spermidine reduces overall mortality as well as disease-specific mortality from cancer and cardiovascular disorders [46-48], supporting prior evidence in yeast, nematodes, fruit flies and mice that spermidine delays age-associated disease and death [30, 45].

Given that autophagy seems to antagonize obesityassociated disease pathogenesis $[35,49]$, we searched for novel ways to stimulate this process. Back in 2010, several

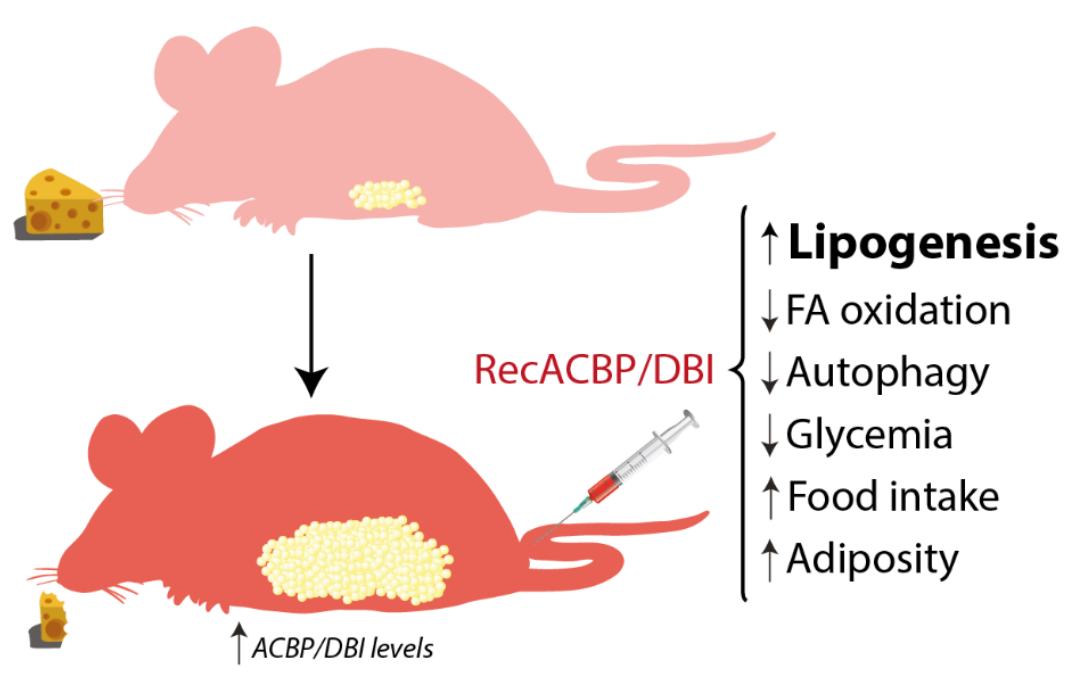

FIGURE 1: Effects of recombinant ACBP/DBI in mice. Metabolic effects detailed after intravenous injection of recombinant $\mathrm{ACBP} / \mathrm{DBI}$ (recACBP/DBI) protein, including an increase of lipogenesis, food intake and consequent adiposity and decrease of autophagy, glycemia and fatty acid (FA) oxidation. 
groups reported that fungal species can release one particular protein, acyl-coenzyme A binding protein (ACBP, also known as diazepam-binding inhibitor, DBI) in an autophagy-dependent fashion [50-52]. Based on the fact that cell stress is usually communicated to other cells, a phenomenon that can be referred to 'inside-outside communication' [53], we wondered whether extracellular ACBP/DBI protein might be a target for modulating autophagy or even impact on pathogenic processes. In mice and humans, ACBP/DBI is ubiquitously expressed (though particularly high in adipocytes, https://www.proteinatlas.org//. As indicated by its dual name, ACBP/DBI has two functions, as an intracellular buffer and transporter for acyl coenzyme A, and as a modulator of benzodiazepine receptors (and in particular the gamma-aminobutyric acid (GABA) A receptor) [54-56]. Intriguingly, we found that any type of human or murine cell released ACBP/DBI upon starvation (which is the most physiological stimulus of autophagy) in vitro and in vivo through a process that can be inhibited by deletion of essential autophagy genes or by pharmacological autophagy inhibitors [57]. Thus, the autophagy-associated release of intracellular $\mathrm{ACBP} / \mathrm{DBI}$ into the extracellular space appears to be a general, phylogenetically conserved phenomenon that applies to both fungal and mammalian systems.

We then set out to determine the effects of $A C B P / D B I$ on autophagy and general metabolism. Interestingly, in human and mouse cell cultures the depletion of intracellular and extracellular ACBP/DBI do not have the same effects on autophagy. Depletion of intracellular ACBP/DBI by small interfering RNAs (siRNAs) inhibits autophagy, while neutralization of extracellular ACBP/DBI with suitable antibodies stimulates autophagy [57]. These results may be interpreted to mean that the autophagy-associated secretion of ACBP/DBI is involved in a negative feedback loop limiting autophagy. In mice, fasting was associated with an increase in the plasma concentration of $A C B P / D B I$, and intravenous injection of recombinant $A C B P / D B I$ protein inhibited starvation-induced autophagy, while $A C B P / D B I$ neutralization (by means of an intraperitoneally injected antibody) enhanced autophagy [57].

Intravenous injection of recombinant ACBP/DBI protein had multiple effects on metabolism (Fig. 1) including a rapid (30 $\mathrm{min}$ ) increase in the expression of the glucose transporter GLUT1 on hepatocytes. This was accompanied by a reduction in plasma glucose levels that could be prevented by GLUT1 inhibitors. Experiments involving isotopelabelled glucose revealed the presence of labeled-glucose in the adipose tissue a few hours after ACBP/DBI injection. ACBP/DBI concomitantly inhibited fatty acid oxidation. Most importantly, mice injected with ACBP/DBI manifested a close-to-immediate ( $30 \mathrm{~min}$ ) hyperphagic response that was accompanied by the activation of orexigenic neurons in the hypothalamus. When glucose levels were maintained in an artificial fashion (by injection of glucose into the peritoneal cavity) both hyperphagy and the activation of orexigenic neurons were prevented, suggesting that the effects of $A C B P / D B I$ on central appetite control were secondary to its metabolic effects on peripheral tissues. Of note, in this time frame ACBP/DBI injection did not affect insulin or ghrelin levels. Of note, sustained overexpression of a transgene coding for ACBP/DBI in hepatocytes was sufficient to cause a significant increase in weight gain coupled to an augmentation of perigonadal and visceral adiposity [57].

Altogether, the aforementioned data suggest that $\mathrm{ACBP} / \mathrm{DB} \mathrm{I}$ is an orexigenic and obesogenic factor. In accord with this interpretation, neutralization of $A C B P / D B I$ had anorexigenic and lipolytic effects (Fig. 2). Thus, the hyperphagic response of mice that had been starved for 24 hours (which causes $\sim 10 \%$ weight loss) was largely abolished by intraperitoneal injection of neutralizing ACBP/DBI antibodies, which, in parallel, prevented the reduction of glycemia that normally accompanies a 24-hour fasting period, caused a decrease in circulating insulin levels, and caused the activation of anorexigenic neurons in the hypothalamus. In mice, $A C B P / D B I$ neutralization led to in-

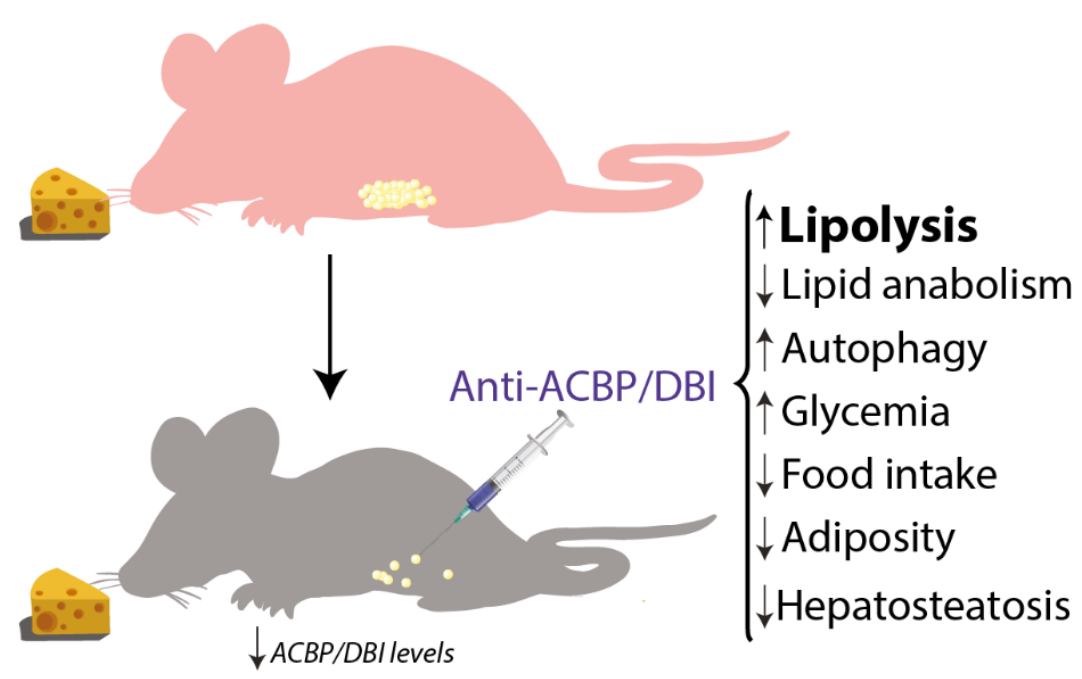

FIGURE 2: ACBP/DBI neutralization and its effects in mice. Metabolic effects observed after intraperitoneal injection of neutralizing antiACBP/DBI antibody, including an increase of lipolysis, glycemia and autophagy and decrease of lipogenesis, food intake, hepatosteatosis and body weight. 
creased lipolysis from white adipose tissue, an increase in gluconeogenesis from glycerol (which may explain the maintenance of glucose levels), as well as an important raise in fatty acid oxidation. ACBP/DBI neutralization could be achieved for longer periods by a specific immunization protocol designed to break autotolerance and to elicit autoantibodies against ACBP/DBI. The surge in neutralizing $A C B P / D B I$ autoantibodies led to a reduction in weight gain induced by high-fat diet (in normal mice) or by feeding a normal diet to leptin-deficient $(O b / O b)$ mice. These effects were accompanied by a reduction in the abundance of white adipose tissue, a reduction in the median diameter of adipocytes, browning of fat, amelioration of the glucose tolerance test, as well as a reduction of hepatosteatosis. Of note, an inducible whole-body knockout of ACBP/DBI recapitulated many of these features, suggesting that the predominant effect of both (intracellular + extracellular) pools of ACBP/DBI is indeed orexigenic and obesogenic [57]. In a plausible scenario, ACBP/DBI would be involved in a 'hunger reflex' in which starvation leads to a transient, autophagy-dependent release of ACBP/DBI from tissues, and extracellular ACBP/DBI then causes metabolic changes that ultimately stimulate feeding behavior, favor lipo-anabolic reactions and inhibit catabolic pathways including autophagy (Fig. 3).

We also examined the levels of ACBP/DBI expression in patients with anorexia and obesity. Of note, we found a high (Spearman $r>0.8$ ) positive correlation between the body mass index and plasma ACBP/DBI levels across several patient cohorts. Thus, anorexic patients manifested subnormal ACBP/DBI plasma concentrations, while obese individuals were characterized by supranormal ACBP/DBI. After successful bariatric surgery $A C B P / D B I$ levels decline when patients lose weight, but increase again when they relapse. Dietary interventions that cause transient weight loss also temporarily reduce $A C B P / D B I$ mRNA expression in the periumbilical fat tissue [57]. In mice, we observed a similar trend. Murine obesity was associated with higher $\mathrm{ACBP} / \mathrm{DBI}$ plasma concentrations, as well as with increased $A C B P / D B I$ mRNA and protein expression in the liver and white adipose tissue. In obese humans, we found a positive association between, on one hand, plasma ACBP/DBI and, on the other hand, fasting insulin levels as well as aspartate transaminases (AST). Thus, ACBP/DBI correlates with laboratory parameters indicative of insulin-resistant (type 2) diabetes and liver damage [57]. However, such clinical observations do not allow to establish any cause-effect relationships beyond these correlations.

Altogether, these results support the notion that $\mathrm{ACBP} / \mathrm{DBI}$ has not only an obesogenic function in mice but that it is indeed increased in obesity in humans. Thus, at difference with leptin and ghrelin, ACBP/DBI exhibits a concordant (rather than discordant) behavior in mice and in humans with eating disorders (Table 1). At this stage, we postulate that ACBP/DBI may well be the elusive 'hunger factor' that is elevated in obesity. Obviously, clinical studies must be designed to neutralize ACBP/DBI or its receptor and to validate this assumption.

\section{ACKNOWLEDGMENTS}

GK is supported by the Ligue contre le Cancer (équipe labellisée); Agence National de la Recherche (ANR) - Projets blancs; ANR under the frame of E-Rare-2, the ERA-Net for Research on Rare Diseases; Association pour la recherche sur le cancer (ARC); Association "Le Cancer du Sein, Parlons-en!", Cancéropôle Ile-de-France; Chancelerie des universités de Paris (Legs Poix), Fondation pour la Recherche Médicale (FRM); a donation by Elior; European Research Area Network on Cardiovascular Diseases (ERA-CVD, MINOTAUR); Gustave Roussy Odyssea, the European Union

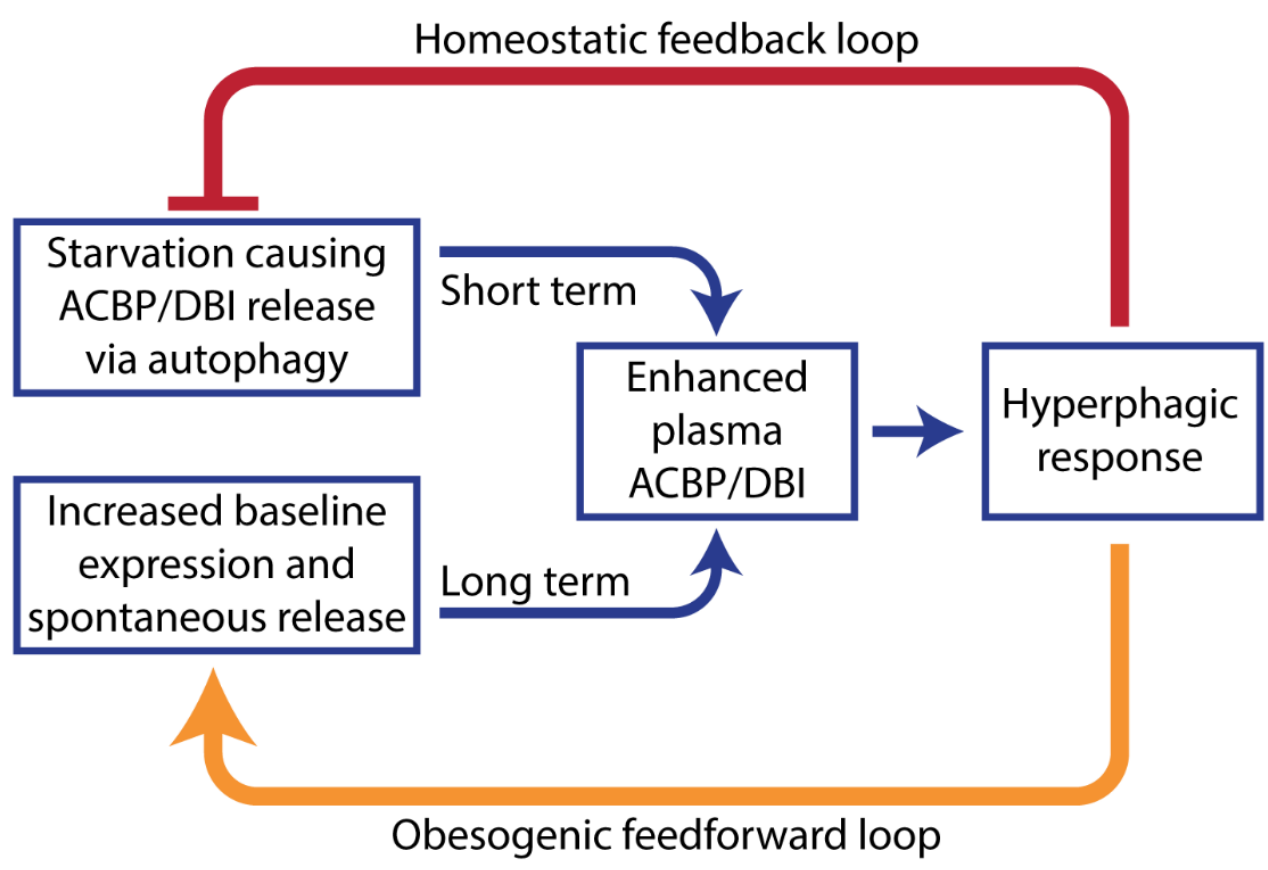

FIGURE 3: The 'hunger reflex'. Hypothetical explanation of the pathogenesis of obesity. Extracellular ACBP/DBI participates in a short-term homeostatic feedback loop to link starvation to food intake. However, obesity causes an increase in ACBP/DBI expression and its spontaneous release that leads to chronic hyperphagy, thus locking the disease in a pathogenic feedforward loop. 
Table 1. Comparison among major appetite control systems in mice and human obesity.

\begin{tabular}{ll|l|l}
\hline & Mouse & Human & Observation \\
\hline Leptin & $\begin{array}{l}\text { Genetic deficiency of leptin or its } \\
\text { receptor causes hyperphagy and } \\
\text { obesity. }\end{array}$ & High in obesity & $\begin{array}{l}\text { Paradoxical association of human } \\
\text { hyperphagy with high levels of an } \\
\text { anorexigenic factor. }\end{array}$ \\
\hline Ghrelin & $\begin{array}{l}\text { Administration of ghrelin causes hy- } \\
\text { perphagy and obesity. }\end{array}$ & $\begin{array}{l}\text { Low in obesity nervosa } \\
\text { hyperphagy with low levels of an } \\
\text { orexigenic factor. }\end{array}$ \\
\hline ACBP/DBI & $\begin{array}{l}\text { ACBP/DBI administration causes hy- } \\
\text { perphagy and obesity, while neutrali- } \\
\text { zation of ACBP/DBI is anorexigenic. }\end{array}$ & High in obesity & $\begin{array}{l}\text { Concordant association of human } \\
\text { hyperphagy with high levels of an } \\
\text { orexigenic factor. }\end{array}$ \\
\hline
\end{tabular}

Horizon 2020 Project Oncobiome; Fondation Carrefour; High-end Foreign Expert Program in China (GDW20171100085), Institut National du Cancer (INCa); Inserm (HTE); Inserm Transfert, Institut Universitaire de France; LeDucq Foundation; the LabEx Immuno-Oncology (ANR-18-IDEX-0001); the RHU Torino Lumière; the Seerave Foundation; the SIRIC Stratified Oncology Cell DNA Repair and Tumor Immune Elimination (SOCRATE); and the SIRIC Cancer Research and Personalized Medicine (CARPEM). F.M. is grateful to the Austrian Science Fund FWF (SFB LIPOTOX F3007 \& F3012, W1226, P29203, P29262, P27893, P 31727 and the Austrian Federal Ministry of Education, Science and Research and the University of Graz for grants "Unkonventionelle Forschung-InterFast" and "flysleep" (BMWFW-80.109/0001-WF/V/3b/2015) as well as the field of excellence program BioHealth. We acknowledge support from NAWI Graz and the BioTechMed-Graz flagship project "EPIAge".

\section{CONFLICT OF INTEREST}

J.M.B.-S.P. and G.K. filed a patent application dealing with targeting the ACBP/DBI system in anorexia, obesity, and co-morbidities. G.K. filed additional patent applications dealing with caloric restriction mimetics (autophagy inducers) for the treatment of aging, age-related diseases, cancer, obesity, and co-morbidities. G.K. is a scientific cofounder of Samsara Therapeutics and Therafast Bio.

\section{COPYRIGHT}

(C) 2019 Bravo-San Pedro et al. This is an open-access article released under the terms of the Creative Commons Attribution (CC BY) license, which allows the unrestricted use, distribution, and reproduction in any medium, provided the original author and source are acknowledged.

Please cite this article as: José Manuel Bravo-San Pedro, Valentina Sica, Frank Madeo and Guido Kroemer (2019). Acyl-CoA-binding protein ( $A C B P$ ): the elusive 'hunger factor' linking autophagy to food intake. Cell Stress 3(10): 312-318. doi: 10.15698/cst2019.10.200

Population genetic differentiation of height and body mass index across Europe. Nat Genet 47(11): 1357-1362. doi: 10.1038/ng.3401

6. Zillikens MC, Demissie S, Hsu YH, Yerges-Armstrong LM, Chou WC Stolk L, Livshits G, Broer L, Johnson T, Koller DL, Kutalik Z, Luan J, Malkin I, Ried JS, Smith AV, Thorleifsson G, Vandenput L, Hua Zhao J, Zhang W, Aghdassi A, Akesson K, Amin N, Baier LJ, Barroso I, Bennett DA, Bertram L, Biffar R, Bochud M, Boehnke M, Borecki IB, et al. (2017). Large meta-analysis of genome-wide association studies identifies five loci for lean body mass. Nat Commun 8(1): 80 . doi: 10.1038/s41467-017-00031-7

7. Turcot $V$, Lu $Y$, Highland HM, Schurmann $C$, Justice $A E$, Fine RS, Bradfield JP, Esko T, Giri A, Graff M, Guo X, Hendricks AE, Karaderi T, Lempradl A, Locke AE, Mahajan A, Marouli E, Sivapalaratnam S, Young KL, Alfred T, Feitosa MF, Masca NGD, Manning AK, Medina-Gomez C, Mudgal P, Ng MCY, Reiner AP, Vedantam S, Willems SM, Winkler TW, et al. (2018). Protein-altering variants associated with body mass index implicate pathways that control energy intake and expenditure in obesity. Nat Genet 50(1): 26-41. doi: 10.1038/s41588-017-0011-x 
8. Halaas JL, Gajiwala KS, Maffei M, Cohen SL, Chait BT, Rabinowitz D, Lallone RL, Burley SK, Friedman JM (1995). Weight-reducing effects of the plasma protein encoded by the obese gene. Science 269(5223): 543-546. doi: 10.1126/science.7624777

9. Lee GH, Proenca R, Montez JM, Carroll KM, Darvishzadeh JG, Lee JI, Friedman JM (1996). Abnormal splicing of the leptin receptor in diabetic mice. Nature 379(6566): 632-635. doi: 10.1038/379632a0

10. Montague CT, Farooqi IS, Whitehead JP, Soos MA, Rau $H$, Wareham NJ, Sewter CP, Digby JE, Mohammed SN, Hurst JA, Cheetham CH, Earley AR, Barnett AH, Prins JB, O'Rahilly S (1997). Congenital leptin deficiency is associated with severe early-onset obesity in humans. Nature 387(6636): 903-908. doi: 10.1038/43185

11. Clement K, Vaisse C, Lahlou N, Cabrol S, Pelloux V, Cassuto D, Gourmelen M, Dina C, Chambaz J, Lacorte JM, Basdevant A, Bougneres P, Lebouc Y, Froguel P, Guy-Grand B (1998). A mutation in the human leptin receptor gene causes obesity and pituitary dysfunction. Nature 392(6674): 398-401. doi: 10.1038/32911

12. Farooqi IS, Jebb SA, Langmack G, Lawrence $\mathrm{E}$, Cheetham $\mathrm{CH}$, Prentice AM, Hughes IA, McCamish MA, O'Rahilly S (1999). Effects of recombinant leptin therapy in a child with congenital leptin deficiency. N Engl J Med 341(12): 879-884. doi: 10.1056/NEJM199909163411204

13. Einerhand MP, Bakx TA, Valerio D (1991). IL-6 production by retrovirus packaging cells and cultured bone marrow cells. Hum Gene Ther 2(4): 301-306. doi: 10.1089/hum.1991.2.4-301

14. Pan WW, Myers MG, Jr. (2018). Leptin and the maintenance of elevated body weight. Nat Rev Neurosci 19(2): 95-105. doi: 10.1038/nrn.2017.168

15. Tschop M, Smiley DL, Heiman ML (2000). Ghrelin induces adiposity in rodents. Nature 407(6806): 908-913. doi: 10.1038/35038090

16. Tschop M, Weyer C, Tataranni PA, Devanarayan V, Ravussin E, Heiman ML (2001). Circulating ghrelin levels are decreased in human obesity. Diabetes 50(4): 707-709. doi: 10.2337/diabetes.50.4.707

17. Makris MC, Alexandrou A, Papatsoutsos EG, Malietzis G, Tsilimigras DI, Guerron AD, Moris D (2017). Ghrelin and Obesity: Identifying Gaps and Dispelling Myths. A Reappraisal. In Vivo 31(6): 1047-1050. doi: 10.21873/invivo.11168

18. Ariyasu H, Takaya K, Tagami T, Ogawa $\mathrm{Y}$, Hosoda K, Akamizu T, Suda M, Koh T, Natsui K, Toyooka S, Shirakami G, Usui T, Shimatsu A, Doi K, Hosoda H, Kojima M, Kangawa K, Nakao K (2001). Stomach is a major source of circulating ghrelin, and feeding state determines plasma ghrelin-like immunoreactivity levels in humans. J Clin Endocrinol Metab 86(10): 4753-4758. doi: 10.1210/jcem.86.10.7885

19. Otto B, Cuntz U, Fruehauf E, Wawarta R, Folwaczny C, Riepl RL, Heiman ML, Lehnert $P$, Fichter $M$, Tschop $M$ (2001). Weight gain decreases elevated plasma ghrelin concentrations of patients with anorexia nervosa. Eur J Endocrinol 145(5): 669-673. doi: 10.1530/eje1450669

20. Hebebrand J, Blum WF, Barth N, Coners H, Englaro P, Juul A, Ziegler A, Warnke A, Rascher W, Remschmidt $H$ (1997). Leptin levels in patients with anorexia nervosa are reduced in the acute stage and elevated upon short-term weight restoration. Mol Psychiatry 2(4): 330-334. doi: 10.1038/sj.mp.4000282

21. Ferron F, Considine RV, Peino R, Lado IG, Dieguez C, Casanueva FF (1997). Serum leptin concentrations in patients with anorexia nervosa, bulimia nervosa and non-specific eating disorders correlate with the body mass index but are independent of the respective disease. Clin Endocrinol 46(3): 289-293. doi: 10.1046/j.1365-2265.1997.1260938.x

22. Galluzzi L, Pietrocola F, Levine B, Kroemer G (2014). Metabolic control of autophagy. Cell 159(6): 1263-1276. doi: 10.1016/j.cell.2014.11.006
23. Levine B, Kroemer G (2019). Biological Functions of Autophagy Genes: A Disease Perspective. Cell 176(1-2): 11-42. doi: 10.1016/j.cell.2018.09.048

24. de Cabo R, Carmona-Gutierrez D, Bernier M, Hall MN, Madeo F (2014). The search for antiaging interventions: from elixirs to fasting regimens. Cell 157(7): 1515-1526. doi: 10.1016/j.cell.2014.05.031

25. Mitchell SJ, Madrigal-Matute J, Scheibye-Knudsen M, Fang E, Aon M, Gonzalez-Reyes JA, Cortassa S, Kaushik S, Gonzalez-Freire M, Patel B, Wahl D, Ali A, Calvo-Rubio M, Buron MI, Guiterrez V, Ward TM, Palacios HH, Cai H, Frederick DW, Hine C, Broeskamp F, Habering L, Dawson J, Beasley TM, Wan J, Ikeno Y, Hubbard G, Becker KG, Zhang $Y$, Bohr VA, et al. (2016). Effects of Sex, Strain, and Energy Intake on Hallmarks of Aging in Mice. Cell Metab 23(6): 1093-1112. doi: 10.1016/j.cmet.2016.05.027

26. Mattson MP, Longo VD, Harvie M (2017). Impact of intermittent fasting on health and disease processes. Ageing Res Rev 39: 46-58. doi: 10.1016/j.arr.2016.10.005

27. Mattson MP, Moehl K, Ghena N, Schmaedick M, Cheng A (2018). Intermittent metabolic switching, neuroplasticity and brain health Nat Rev Neurosci 19(2): 63-80. doi: 10.1038/nrn.2017.156

28. Stekovic S, Hofer SJ, Tripolt N, Aon MA, Royer P, Pein L, Stadler JT, Pendl T, Prietl B, Url J, Schroeder S, Tadic J, Eisenberg T, Magnes C, Stumpe M, Zuegner E, Bordag N, Riedl R, Schmidt A, Kolesnik E, Verheyen N, Springer A, Madl T, Sinner F, de Cabo R, Kroemer G, Obermayer-Pietsch B, Dengjel J, Sourij H, Pieber TR, Madeo F (2019). Alternate day fasting improves physiological and molecular markers of aging in healthy, non-obese humans. Cell Metabolism 30(3):462-476. doi: 10.1016/j.cmet.2019.07.016

29. Tavernarakis N, Pasparaki A, Tasdemir E, Maiuri MC, Kroemer G (2008). The effects of p53 on whole organism longevity are mediated by autophagy. Autophagy 4(7): 870-873. doi: 10.4161/auto.6730

30. Eisenberg $T$, Knauer $H$, Schauer A, Buttner $S$, Ruckenstuhl $C$, Carmona-Gutierrez D, Ring J, Schroeder S, Magnes C, Antonacci L, Fussi H, Deszcz L, Hartl R, Schraml E, Criollo A, Megalou E, Weiskopf D, Laun P, Heeren G, Breitenbach M, Grubeck-Loebenstein B, Herker E, Fahrenkrog B, Frohlich KU, Sinner F, Tavernarakis N, Minois N, Kroemer G, Madeo F (2009). Induction of autophagy by spermidine promotes longevity. Nat Cell Biol 11(11): 1305-1314. doi: $10.1038 /$ ncb1975

31. Morselli E, Maiuri MC, Markaki M, Megalou E, Pasparaki A, Palikaras K, Criollo A, Galluzzi L, Malik SA, Vitale I, Michaud M, Madeo F, Tavernarakis N, Kroemer G (2010). Caloric restriction and resveratrol promote longevity through the Sirtuin-1-dependent induction of autophagy. Cell Death Dis 1: e10. doi: $10.1038 /$ cddis. 2009.8

32. Lopez-Otin C, Galluzzi L, Freije JMP, Madeo F, Kroemer G (2016). Metabolic Control of Longevity. Cell 166(4): 802-821. doi: 10.1016/j.cell.2016.07.031

33. Zhang Y, Sowers JR, Ren J (2018). Targeting autophagy in obesity: from pathophysiology to management. Nat Rev Endocrinol 14(6): 356-376. doi: 10.1038/s41574-018-0009-1

34. Nunez CE, Rodrigues VS, Gomes FS, Moura RF, Victorio SC, Bombassaro B, Chaim EA, Pareja JC, Geloneze B, Velloso LA, Araujo EP (2013). Defective regulation of adipose tissue autophagy in obesity. Int J Obes 37(11): 1473-1480. doi: 10.1038/ijo.2013.27

35. Fernandez AF, Barcena C, Martinez-Garcia GG, Tamargo-Gomez I, Suarez MF, Pietrocola F, Castoldi F, Esteban L, Sierra-Filardi E, Boya P, Lopez-Otin C, Kroemer G, Marino G (2017). Autophagy couteracts weight gain, lipotoxicity and pancreatic beta-cell death upon hypercaloric pro-diabetic regimens. Cell Death Dis 8(8): e2970. doi: 10.1038/cddis.2017.373 
36. Sciarretta S, Volpe M, Sadoshima J (2012). Is reactivation of autophagy a possible therapeutic solution for obesity and metabolic syndrome? Autophagy 8(8): 1252-1254. doi: 10.4161/auto.20670

37. Madeo F, Tavernarakis N, Kroemer G (2010). Can autophagy promote longevity? Nat Cell Biol 12(9): 842-846. doi: 10.1038/ncb0910-842

38. Madeo F, Pietrocola F, Eisenberg T, Kroemer G (2014). Caloric restriction mimetics: towards a molecular definition. Nat Rev Drug Discov 13(10): 727-740. doi: 10.1038/nrd4391

39. Madeo F, Carmona-Gutierrez D, Hofer SJ, Kroemer G (2019). Caloric Restriction Mimetics against Age-Associated Disease: Targets, Mechanisms, and Therapeutic Potential. Cell Metab 29(3): 592-610. doi: 10.1016/j.cmet.2019.01.018

40. Marino G, Pietrocola F, Eisenberg $T$, Kong $Y$, Malik SA, Andryushkova A, Schroeder S, Pendl T, Harger A, Niso-Santano M, Zamzami N, Scoazec M, Durand S, Enot DP, Fernandez AF, Martins I, Kepp O, Senovilla L, Bauvy C, Morselli E, Vacchelli E, Bennetzen M, Magnes C, Sinner F, Pieber T, Lopez-Otin C, Maiuri MC, Codogno P, Andersen JS, Hill JA, et al. (2014). Regulation of autophagy by cytosolic acetyl-coenzyme A. Mol Cell 53(5): 710-725. doi: 10.1016/j.molcel.2014.01.016

41. Eisenberg $T$, Schroeder $S$, Andryushkova A, Pendl $T$, Kuttner V, Bhukel A, Marino G, Pietrocola F, Harger A, Zimmermann A, Moustafa T, Sprenger A, Jany E, Buttner S, Carmona-Gutierrez D, Ruckenstuhl C, Ring J, Reichelt W, Schimmel K, Leeb T, Moser C, Schatz S, Kamolz LP, Magnes C, Sinner F, Sedej S, Frohlich KU, Juhasz G, Pieber TR, Dengjel $\mathrm{J}$, et al. (2014). Nucleocytosolic depletion of the energy metabolite acetyl-coenzyme a stimulates autophagy and prolongs lifespan. Cell Metab 19(3): 431-444. doi: 10.1016/j.cmet.2014.02.010

42. Pietrocola F, Castoldi F, Markaki M, Lachkar S, Chen G, Enot DP, Durand S, Bossut N, Tong M, Malik SA, Loos F, Dupont N, Marino G, Abdelkader N, Madeo F, Maiuri MC, Kroemer R, Codogno P, Sadoshima J, Tavernarakis N, Kroemer G (2018). Aspirin Recapitulates Features of Caloric Restriction. Cell Rep 22(9): 2395-2407. doi: 10.1016/j.celrep.2018.02.024

43. Carmona-Gutierrez D, Zimmermann A, Kainz K, Pietrocola F, Chen G, Maglioni S, Schiavi A, Nah J, Mertel S, Beuschel CB, Castoldi F, Sica V, Trausinger G, Raml R, Sommer C, Schroeder S, Hofer SJ, Bauer MA, Pendl T, Tadic J, Dammbrueck C, Hu Z, Ruckenstuhl C, Eisenberg T, Durand S, Bossut N, Aprahamian F, Abdellatif M, Sedej S, Enot DP, et al. (2019). The flavonoid 4,4'-dimethoxychalcone promotes autophagy-dependent longevity across species. Nat Commun 10(1): 651. doi: 10.1038/s41467-019-08555-w

44. Morselli E, Marino G, Bennetzen MV, Eisenberg T, Megalou E, Schroeder S, Cabrera S, Benit P, Rustin P, Criollo A, Kepp O, Galluzzi L, Shen S, Malik SA, Maiuri MC, Horio Y, Lopez-Otin C, Andersen JS, Tavernarakis N, Madeo F, Kroemer G (2011). Spermidine and resveratrol induce autophagy by distinct pathways converging on the acetylproteome. J Cell Biol 192(4): 615-629. doi: $10.1083 /$ jcb. 201008167

45. Madeo F, Eisenberg T, Pietrocola F, Kroemer G (2018). Spermidine in health and disease. Science 359(6374). doi: 10.1126/science.aan2788
46. Eisenberg $T$, Abdellatif $M$, Schroeder $S$, Primessnig $U$, Stekovic $S$, Pendl T, Harger A, Schipke J, Zimmermann A, Schmidt A, Tong M, Ruckenstuhl C, Dammbrueck C, Gross AS, Herbst V, Magnes C, Trausinger G, Narath S, Meinitzer A, Hu Z, Kirsch A, Eller K, CarmonaGutierrez D, Buttner S, Pietrocola F, Knittelfelder O, Schrepfer E, Rockenfeller P, Simonini C, Rahn A, et al. (2016). Cardioprotection and lifespan extension by the natural polyamine spermidine. Nat Med 22(12): 1428-1438. doi: 10.1038/nm.4222

47. Kiechl S, Pechlaner R, Willeit $P$, Notdurfter M, Paulweber B, Willeit K, Werner P, Ruckenstuhl C, Iglseder B, Weger S, Mairhofer B, Gartner M, Kedenko L, Chmelikova M, Stekovic S, Stuppner H, Oberhollenzer F, Kroemer G, Mayr M, Eisenberg T, Tilg H, Madeo F, Willeit J (2018). Higher spermidine intake is linked to lower mortality: a prospective population-based study. Am J Clin Nutr 108(2): 371-380. doi: 10.1093/ajcn/nqy102

48. Pietrocola F, Castoldi F, Kepp O, Carmona-Gutierrez D, Madeo F, Kroemer $G$ (2019). Spermidine reduces cancer-related mortality in humans. Autophagy 15(2): 362-365. doi: 10.1080/15548627.2018.1539592

49. Lim H, Lee MS (2018). Amelioration of obesity-induced diabetes by a novel autophagy enhancer. Cell Stress 2(7): 181-183. doi: 10.15698/cst2018.07.146

50. Manjithaya R, Anjard C, Loomis WF, Subramani S (2010) Unconventional secretion of Pichia pastoris Acb1 is dependent on GRASP protein, peroxisomal functions, and autophagosome formation. J Cell Biol 188(4): 537-546. doi: 10.1083/jcb.200911149

51. Duran JM, Anjard C, Stefan C, Loomis WF, Malhotra V (2010). Unconventional secretion of Acb1 is mediated by autophagosomes. J Cell Biol 188(4): 527-536. doi: 10.1083/jcb.200911154

52. Abrahamsen $\mathrm{H}$, Stenmark $\mathrm{H}$ (2010). Protein secretion: unconventional exit by exophagy. Curr Biol 20(9): R415-418. doi: 10.1016/j.cub.2010.03.011

53. Galluzzi L, Yamazaki T, Kroemer G (2018). Linking cellular stress responses to systemic homeostasis. Nat Rev Mol Cell Biol 19(11): 731745. doi: 10.1038/s41580-018-0068-0

54. Knudsen J, Neergaard TB, Gaigg B, Jensen MV, Hansen JK (2000). Role of acyl-CoA binding protein in acyl-CoA metabolism and acyl-CoAmediated cell signaling. J Nutr 130(2S Suppl): 294S-298S. doi: 10.1093/jn/130.2.294S

55. Neess D, Bek S, Engelsby H, Gallego SF, Faergeman NJ (2015). Long-chain acyl-CoA esters in metabolism and signaling: Role of acylCoA binding proteins. Prog Lipid Res 59: 1-25. doi: 10.1016/j.plipres.2015.04.001

56. Farzampour Z, Reimer RJ, Huguenard J (2015). Endozepines. Adv Pharmacol 72: 147-164. doi: 10.1016/bs.apha.2014.10.005

57. Bravo-San Pedro JM, Sica V, Martins I, Pol J, Loos F, Maiuri MC, Durand S, Bossut N, Aprahamian F, Anagnostopoulos G, Niso-Santano M, Aranda F, Ramirez-Pardo I, Lallement J, Denom J, Boedec E, Gorwood P, Ramoz N, Clement K, Pelloux V, Rohia A, Pattou F, Raverdy V, Caiazzo R, Denis RGP, Boya P, Galluzzi L, Madeo F, Migrenne-Li S, Cruciani-Guglielmacci C, et al. (2019). Acyl-CoA-Binding Protein Is a Lipogenic Factor that Triggers Food Intake and Obesity. Cell Metab. doi: 10.1016/j.cmet.2019.07.010 